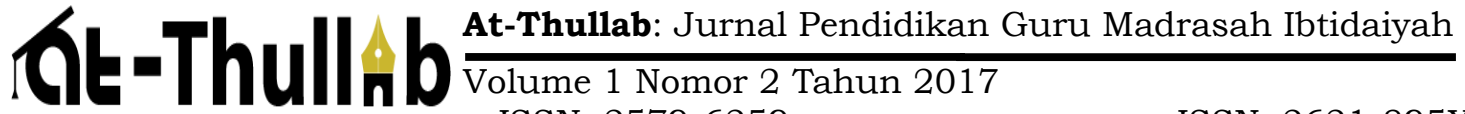

\section{HAKIKAT BELAJAR DAN PEMBELAJARAN}

\author{
Silviana Nur Faizah \\ Program Studi Pendidikan Guru Madrasah Ibtidaiyah \\ Universitas Islam Lamongan \\ e-mail : silviana_nurfaizah@yahoo.com
}

\begin{abstract}
Learning is a process that must be done by every individual to get knowledge. It is considerably a fundamental element in the implementation of any education level. The success of education depends on the student learning process both within and outside the school. In formal education the learning process is inseparable from to the teaching and learning process. Both of these processes are synergized to realize the ideals of the nation in order to educate the life of the world. As learning creatures and educational practitioners, whatever related to learning is important to know. Learning is a conscious activity undertaken by individuals through training and experiences that produce behavioral changes that include the cognitive, affective and psychomotor aspects. While teaching and learning is a system or process of teaching subject matters that are planned, implemented, and evaluated systematically so that students can achieve the learning objectives effectively and efficiently. Three learning characteristics are: (a) learning is a conscious effort of a person, (b) learning is characterized by a change of behavior that encompasses all aspects (cognitive, affective, and psychomotor), and such changes are relatively permanent, $(c)$ changes in behavior are derived from the interaction process with the environment and exercises. Factors that influence learning and teaching process are internal factors (physiological and psychological) and external factors (family, school and community). Five principles of learning: subsumption, organizer progressive differentiation concolidation integrative Reconciliation.
\end{abstract}

Keywords: Learning process, education, environment

\section{A. Pendahuluan}

Pendidikan pada dasarnya berfungsi untuk membantu peserta didik dalam pengembangan dirinya, yaitu pengembangan semua potensi, kecakapan, serta karateristik pribadinya kearah yang positif, baik bagi diri maupun lingkungannya. Proses pendidikan agaknya tidak luput dari beberapa aktivitas diantaranya adalah belajar dan pembelajaran.

Pentingnya belajar dan pembelajaran untuk menjadikan insan yang kamil ditunjukkan dari beberapa ayat dalam al-Qur'an yang menjelaskan pentingya belajar salah satunya terdapat dalam al-Qur'an surat Al-Alaq ayat 1-5 selain itu terdapat beberapa hadits Nabi Muhammad saw. yang juga membahas tentang pentingnya belajar. 
Hakikat belajar dan pembelajaran perlu dipelajari secara mendalam untuk mengetahui batasan-batasan dari masing-masing istilah tersebut. Belajar merupakan suatu aktifitas sadar yang dilakukan oleh individu melalui latihan maupun pengalaman yang menghasilkan perubahan tingkah laku yang mencakup aspek kognitif, afektif dan psikomotorik. Selain mengetahui hakekat belajar komponen-komponen yang berada didalamnya seperti ciri-ciri belajar, faktor-faktor yang mempengaruhi belajar, dan prinsip-prinsip belajar menjadi penting untuk dikaji.

\section{Pengertian Belajar}

Secara etimologis dalam kamus besar bahasa Indonesia, belajar memiliki arti "berusaha memperoleh kepandaian atau ilmu" (Tim Penyusun Kamus, 1996). Dalam alQur'an banyak ayat yang menunjukkan aktivitas belajar, di antaranya surat an-Nahl ayat 78:

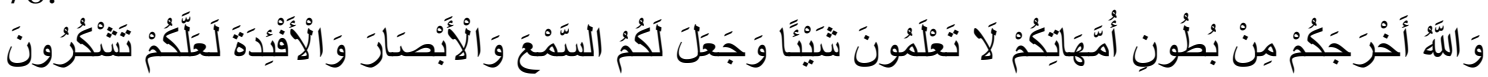

(Al-Qur'an, $16: 78) \quad(\vee \wedge \wedge)$

"Dan Allah mengeluarkan kamu dari perut ibumu dalam keadaan tidak mengetahui sesuatupun, dan Dia memberi kamu pendengaran, penglihatan dan hati agar kamu bersyukur" (Departemen Agama RI, 2004).

Kata belajar dalam Istilah bahasa Arab disebut dengan Ta'allama dan Darasa. AlQuran menggunakan kata Darasa yang diartikan mempelajari yang sering dihubungkan dengan mempelajari Al-kitab (Al-Qur'an). Diantaranya terdapat dalam Al-Qur'an surah Al-An'am ayat 105:

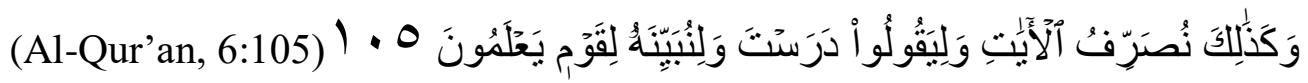

"Dan demikianlah Kami menjelaskan berulang-ulang ayat-ayat Kami agar orangorang musyrik mengatakan engkau telah mempelajari ayat-ayat itu (dari ahli kitab) dan agar Kami menjelaskan al-Qur'an itu kepada orang-orang yang mengetahui" (Departemen Agama RI, 2004).

Kata darasta yang berarti "engkau telah mempelajari”, menurut Quraish Shihab yaitu membaca dengan seksama untuk dihafal atau dimengerti. (Shihab, 2002) Istilah belajar dalam islam sering disebut dengan menuntut ilmu (Thalab A-'Ilm). Karena dengan belajar, seseorang akan mendapatkan ilmu pengetahuan yang bermanfaat bagi dirinya, dan ilmu yang diperoleh harus diaplikasikan sehingga memberikan perubahan dalam diri pelajar, baik kepribadian maupun perilakunya.

Belajar mempunyai pengertian yang sangat kompleks, sehingga banyak ahli yang mengemukakan pengertian belajar dengan ungkapan yang berbeda-beda. Hal 
tersebut dikarenakan mereka mempunnyai sudut pandang tertentu mengenai batasanbatasan pengertian belajar.

Croanbach memberikan definisi: "learning is shown by a change in behaviour as a result of experience"(Sardiman, 1994) belajar ditunjukkan oleh perubahan perilaku sebagai hasil dari pengalaman. Pendapat serupa dikemukakan oleh Mouly bahwa belajar pada hakekatnya adalah perubahan tingkah laku seseorang berkat adanya pengalaman (Mufarrokah, 2009). Pidarta juga mendifinisikan belajar adalah perubahan tingkah laku yang relative sebagai hasil pengalaman (bukan hasil perkembangan, pengaruh obat, atau kecelakaan) dan bisa melaksanakannya pada pengetahuan lain serta mampu mengkomunikasikannya kepada orang lain (Komsiyah, 2012).

Sedangkan menurut Syekh Abdul Aziz dan Abdul Majid dalam kitab AtTarbiyatul wa Thuruqut Tadris mendenifisikan belajar sebagai berikut:

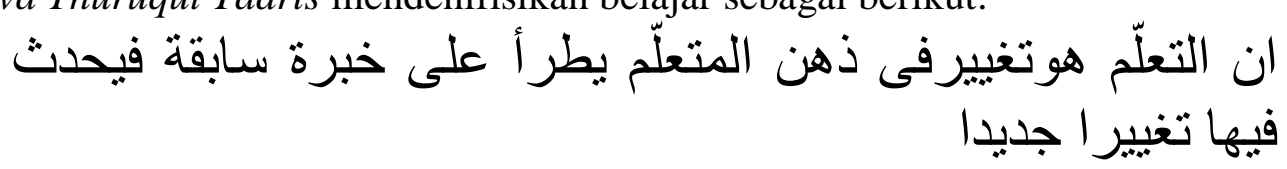

“(Belajar adalah perubahan di dalam diri (jiwa) peserta didik yang dihasilkan dari pengalaman terdahulu sehingga menimbulkan perubahan yang baru)" (Majid, n.d.)

Mahmud mendefinisikan belajar adalah perubahan dalam kepribadian yang dimanifestasikan sebagai pola-pola respons yang baru berbentuk keterampilan, sikap, kebiasaan-kebiasaan, pengetahuan, dan kecakapan (Mahmud, 2010) . Menurut Kokom belajar adalah suatu proses perubahan tingkah laku dalam pengetahuan, sikap, dan keterampilan yang diperoleh dalam jangka waktu yang lama dan dengan syarat bahwa perubahan yang terjadi tidak disebabkan oleh adanya kematangan atau perubahan sementara karena suatu hal (Komalasari, 2010).

Harold Spears memberikan batasan:"learning is to observe, to read, to imitate, to try something themselves, to listen, to follow direction" (Sardiman, 1994). belajar adalah untuk mengamati , membaca, meniru , mencoba sesuatu sendiri , mendengarkan , mengikuti arah. Sedangkan menurut Nana Sudjana, belajar adalah proses perubahan tingkah laku seseorang berkat pengalaman dan latihan (Sudjana, 1989b).

Dari berbagai perspektif pengertian belajar sebagaimana dijelaskan diatas, maka dapat disimpulkan bahwa, belajar adalah suatu aktifitas sadar yang dilakukan oleh individu melalui latihan maupun pengalaman yang menghasilkan perubahan tingkah laku yang mencakup aspek kognitif, afektif dan psikomotorik.

Belajar merupakan aktivitas sangat terkait dengan proses pencarian ilmu. Islam sangat menekan terhadap pentingnya ilmu. Al-Quran dan Hadis mengajak umat Islam untuk mencari dan mendapatkan ilmu dan kearifan, serta menempatkan orang-orang yang berpengatahuan pada derajat yang tinggi (Wahyuni, 2010). 
Di dalam Al-Quran, kata al- ilm dan kata-kata turunannya digunakan lebih dari 780 kali. Beberapa ayat pertama yang diwahyukan kepada Rasulullah Saw, menyebutkan pentingnya membaca, pena dan ajaran untuk manusia (Wahyuni, 2010). Sebagaimana yang tertera dalam surah Al-'alaq ayat 1-5:

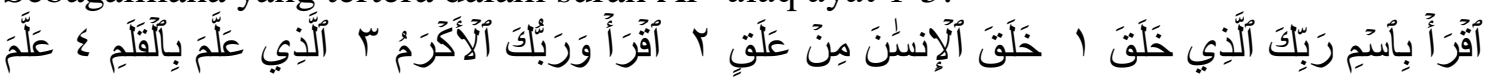

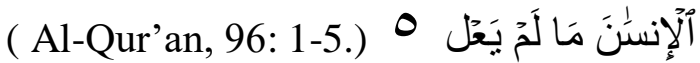

"Bacalah dengan (menyebut) nama Tuhanmu yang Menciptakan. Dia telah menciptakan manusia dari segumpal darah. Bacalah, dan Tuhanmulah yang Maha pemurah. yang mengajar (manusia) dengan perantaran kalam. Dia mengajar kepada manusia apa yang tidak diketahuinya" (Departemen Agama RI, 2004).

Sejak turunnya wahyu pertama kepada Nabi Muhammad Saw., islam telah menekankan perintah untuk belajar. Ayat pertama menjadi bukti bahwa Al-Qur'an memandang pentingnya belajar agar manusia memahami seluruh kejadian yang ada disekitarnya, sehingga meningkatkan rasa syukur mengakui akan kebesaran Allah Swt. Pada ayat pertama dalam surah Al- 'alaq terdapat kata iqra', yang melalui malaikat Jibril Allah memerintahkan kepada Nabi Muhammad untuk "membaca".

Quraisy Shihab didalam Tafsirnya Al-Misbah kata iqra' berasal dari kata Qara'a berarti menghimpun. Dan dari kata menghimpun itu ditemukan berbagai macam arti. Antara lain: menyampaikan, menelaah, membaca, mendalami, meneliti, mengetahui ciri-ciri sesuatu dan sebagainya, yang ke semuanya bermuara pada arti menghimpun (Shihab, 2002).

Bahkan Quraish Shihab berpendapat bahwa ayat di atas seakan akan mengatakan: bacalah wahyu-wahyu ilahi yang sebentar lagi akan banyak engkau terima, dan baca juga alam dan masyarakatmu. Bacalah agar engkau membekali dirimu dengan kekuatan pengetahuan. Akan tetapi dengan satu syarat engkau lakukan dengan atau nama tuhan yang selalu memelihara dan membimbingmu dan yang mencipta semua makhluk kapan dan di manapun (Shihab, 2002).

Selain Al-Qur'an, banyak Hadis Nabi Saw. Yang menjelaskan betapa pentingnya ilmu dan orang-orang yang terdidik. Diantara Hadis-hadis tentang pentingnya belajar dan menuntut ilmu, antara lain, adalah: mencari ilmu itu wajib bagi setiap muslim; carilah ilmu walaupun ke negeri cina; carilah ilmu sejak dalam buaian sampai ke liang lahat; para ulama itu adalah pewaris para Nabi; pada hari kiamat ditimbanglah tinta ulama dengan darah syuhada,maka tinta ulama dilebihkan dari darah syuhada (Wahyuni, 2010). 


\section{Pengertian Pembelajaran}

Pembelajaran dapat didefinisikan sebagai suatu sistem atau proses membelajarkan subjek didik/pembelajar yang direncanakan atau didesain, dilaksanakan, dievaluasi secara sistematis agar subjek didik/pembelajar dapat mencapai tujuan-tujuan pembelajaran secara efektif dan efisien (Komalasari, 2010). Terdapat dua konsep yang tidak bisa dipisahkan dalam kegiatan pembelajaran yaitu belajar dan mengajar. Belajar mengacu kepada apa yang dilakukan siswa, sedang mengajar mengacu kepada apa yang dilakukan oleh guru (Mufarrokah, 2009).

Pembelajaran dapat dipandang dari dua sudut, pertama pembelajaran dipandang sebagai suatu sistem, pembelajaran terdiri dari sejumlah komponen yang terorganisasi antara lain tujuan pembelajaran, media pembelajaran, pengorganisasian kelas, evaluasi pembelajaran, dan tindak lanjut pembelajaran (remedial dan pengayaan).

Kedua, pembelajaran dipandang sebagai suatu proses yang meliputi kegiatan yang dilakukan oleh guru mulai dari perencanaan, pelaksanaan kegiatan sampai evaluasi dan program tindak lanjut yang berlangsung dalam situasi edukatif untuk mencapai tujuan pembelajaran yang telah ditetapkan (Subroto, 1997).

Kokom menjelaskan secara lebih rinci ketiga proses pembelajaran tersebut dari masing-masing kegiatan pembelajaran:

1. Persiapan, dimulai dari merencanakan program pengajaran tahunan, semester, dan penyusunan persiapan mengajar (lesson plan) penyiapan alat kelengkapannya, antara lain berupa alat peraga dan alat-alat evaluasi.

2. Melaksanakan kegiatan pembelajaran dengan mengacu pada persiapan pembelajaran yang telah dibuatnya. Struktur dan situasi pembelajaran yang diwujudkan guru akan banyak dipengaruhi oleh pendekatan atau strategi dan metode-metode pembelajaran yang telah dirancang penerapannya.

3. Menindaklanjuti pembelajaran yang telah dikelolanya. Kegiatan pasca pembelajaran ini dapat berbentuk enrichment (pengayaan), dapat pula berupa pemberian layanan remidial teaching bagi siswa yang berkesulitan belajar (Komalasari, 2010).

\section{Ciri-ciri Belajar}

Ciri-ciri belajar menurut Eveline Siregar dan Hartini Nara diantaranya adalah:

1. Belajar ditandai dengan adanya perubahan tingkah laku (change behavior).

2. Perubahan perilaku relative permanent.

3. Perubahan tingkah laku tidak harus segera dapat diamati pada saat proses belajar sedang berlangsung, perubahan perilaku tersebut bersifat potensial.

4. Perubahan tingkah laku merupakan hasil latihan atau pengalaman.

5. Pengalaman atau latihan itu dapat memberi penguatan (Wahyuni, 2010).

Slameto mengungkapkan enam kriteria perubahan tingkah laku dalam pengertian belajar, yaitu sebagai berikut 
1. Perubahan terjadi secara wajar. Seseorang yang belajar akan menyadari terjadinya perubahan, atau sekurang-kurangnya ia merasakan telah terjadi suatu perubahan dalam dirinya.

2. Perubahan dalam belajar bersifat kontinyu dan fungsional. Sebagai hasil belajar, perubahan yang terjadi dalam diri seseorang berlangsung secara berkesinambungan, tidak statis.

3. Perubahan dalam belajar bersifat positif dan aktiv. Dalam perbuatan belajar, perubahan-perubahan senantiasa bertambah dan tertuju untuk memperoleh sesuatu yang lebih baik dari sebelumnya.

4. Perubahan dalam belajar bukan bersifat sementara. Perubahan yang bersifat sementara atau temporer terjadi hanya untuk beberapa saat saja dan tidak dapat digolongkan sebagai perubahan dalam arti belajar seperti berkeringat, keluar air mata, bersin, menangis, dan sebagainya.

5. Perubahan dalam belajar bertujuan dan terarah. Perubahan tingkah laku terjadi karena ada tujuan yang akan dicapai.

6. Perubahan mencakup seluruh aspek tingkah laku. Perubahan yang diperoleh seseorang setelah melalui suatu proses belajar, meliputi perubahan keseluruhan tingkah laku jika seseorang belajar sesuatu (Sahrani, 2011).

Menurut Baharuddin dan Esa Nur Wahyuni, Setidaknya belajar memiliki ciri-ciri sebagai berikut:

1. Adanya kemampuan baru atau perubahan. Perubahan tingkah laku tersebut bersifat pengetahuan (kognitif), keterampilan (psikomotor), maupun nilai dan sikap (afektif).

2. Perubahan itu tidak berlangsung sesaat saja, melainkan menetap atau dapat disimpan.

3. Perubahan itu tidak terjadi begitu saja, melainkan harus dengan usaha. Perubahan terjadi akibat interaksi dengan lingkungan.

4. Perubahan tidak semata-mata disebabkan oleh pertumbuhan fisik atau kedewasaan, tidak karena kelelahan, penyakit, atau pengaruh obat-obatan (Nara, 2010).

Sedangkan Morgan menyebutkan bahwa suatu kegiatan dikatakan belajar apabila memiliki tiga ciri-ciri sebagai berikut. (a). belajar adalah perubahan tingkahlaku; (b). perubahan terjadi karena latihan dan pengalaman, bukan karena pertumbuhan; (c). perubahan tersebut harus bersifat permanen dan tetap ada untuk waktu yang cukup lama (Soekamto, 1997).

Ciri umum belajar menurut Aunurrahman adalah sebagai berikut; Pertama, belajar menunjukkan suatu aktivitas pada diri seseorang yang disadari atu disengaja. Kedua, belajar merupakan interaksi individu dengan lingkungannya. Ketiga, hasil belajar ditandai dengan perubahan tingkah laku (Aunurrahman, 2009). 
Dari beberapa pendapat tersebut dapat disimpulkan ciri belajar diantaranya: Pertama, belajar merupakan usaha sadar dari seseorang, Kedua, belajar ditandai adanya perubahan tingkah laku yang mencakup seluruh aspek (kognitif, afektif, psikomotor), dan perubahan tersebut relative permanent, Ketiga, perubahan tingkah laku tersebut diperoleh dari proses interksi dengan lingkungan dan latihan.

\section{Faktor-faktor yang Mempengaruhi Belajar dan Pembelajaran}

Belajar dan Pembelajaran merupakan dua kegiatan yang tidak dapat dipisahkan satu sama lain. Secara skematik factor yang mempengaruhi belajar dan pembelajaran digambarkan sebagai berikut (Komalasari, 2010):

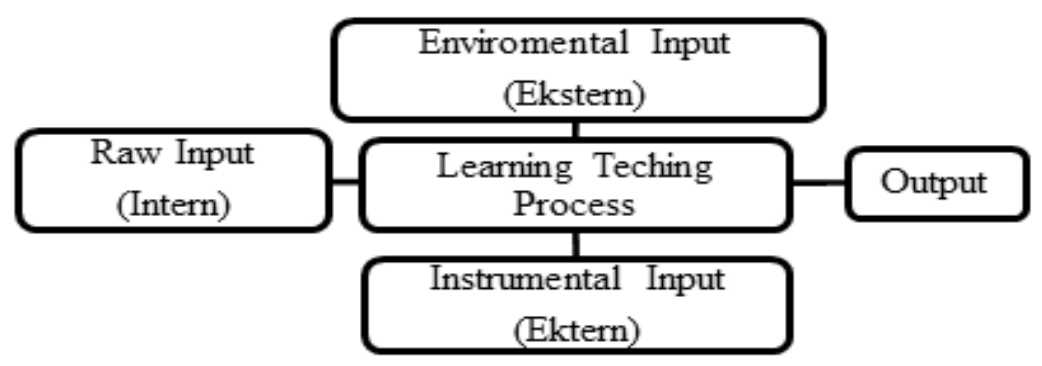

Gambar 1.1 Faktor yang Mempengaruhi Belajar dan Pembelajaran

Berdasarkan skema diatas adapun faktor-faktor yang mempengaruhi belajar dan pembelajaran yaitu faktor intern dan faktor ekstern.

1. Faktor Intern

Faktor intern adalah faktor yang terdapat dalam diri individu itu sendiri. (Sudjana, 1989) Faktor intern ini berkaitan dengan unsur fisiologis dan psikologis siswa. Unsur fisiologis siswa berupa kondisi fisiologis secara umum serta kondisi panca indera. Sedangkan unsur psikologi berupa minat, kecerdasan, bakat, motivasi, dan kemampuan kognitif.

Sedangkan menurut Slameto faktor intern adalah faktor yang ada dalam diri peserta didik. Di dalam membicarakan faktor intern ini, akan dibagi menjadi tiga faktor yaitu faktor jasmaniah, faktor psikologis dan faktor kelelahan.

a) Faktor jasmaniah meliputi faktor kesehatan dan cacat tubuh.

b) Faktor psikologis meliputi intelegensi, perhatian, minat, bakat, motif, kematangan dan kesiapan.

c) Faktor kelelahan dibedakan menjadi dua, yaitu kelelahan jasmani dan rohani. Kelelahan jasmani seperti lemah lunglai sedangkan kelelahan rohani seperti adanya kelesuan dan kebosanan (Slameto, 2006).

2. Faktor Ekstern 
Faktor ekstern adalah faktor yang berasal dari luar diri peserta didik, faktor ekstern dikelompokkan menjadi tiga, yaitu faktor keluarga, faktor sekolah dan faktor masyarakat (Slameto, 2006).

a. Faktor Keluarga

Peserta didik akan dipengaruhi dari keluarga berupa cara orang tua mendidik, relasi antar anggota keluarga, suasana rumah tangga dan keadaan ekonomi keluarga. Di dalam kehidupan keluarga, anak mendapatkan bimbingan dan perawatan dalam rangka membentuk perwatakan dan kepribadian anak, untuk menjadi dirinya sendiri atau menjadi pribadi yang utuh (Isjoni, 2009).

b. Faktor Sekolah

Faktor sekolah yang dapat mempengaruhi belajar yaitu mencakup metode mengajar, kurikulum, relasi guru dan peserta didik, relasi peserta didik dengan peserta didik, disiplin sekolah, pelajaran dan waktu sekolah, standar pengajaran, kualitas pengajaran, keadaan gedung, metode belajar dan tugas rumah.

c. Faktor Masyarakat

Lingkungan masyarakat dimana siswa berada juga berpengaruh terhadap semangat dan aktivitas belajarnya. Lingkungan masyarakat dimana warganya memiliki latar belakang pendidikan yang cukup, terdapat lembaga-lembaga pendidikan dan sumber-sumber belajar yang cukup, terdapat lembaga-lembaga pendidikan dan sumber-sumber belajar di dalamnya akan memberikan pengaruh positif terhadap semangat dan perkembangan belajar generasi mudanya (Sukmadinata, 2004).

\section{Prinsip-prinsip Belajar}

Prinsip belajar ialah petunjuk atau cara yang perlu diikuti untuk melakukan kegiatan belajar (Sutikno, 1995). Peserta didik akan berhasil dalam belajarnya jika memperhatikan prinsip-prinsip belajar. Menurut Ausubel yang dikutip dalam Djadjuri, ada lima prinsip utama belajar yang harus dilaksanakan, yaitu:

1. Subsumption, yaitu proses penggabungan ide atau pengalaman baru terhadap ide-ide yang telah lalu yang telah dimiliki.

2. Organizer, yaitu ide baru yang telah dicoba digabungkan dengan pola ide-ide lama diatas, dicoba diintegrasikan sehingga menjadi suatu kesatuan pengalaman. Dengan prinsip ini dimaksudkan agar pengalaman yang diperoleh itu bukan sederetan pengalaman yang satu dengan yang lainnya terlepas dan hilang kembali. 
3. Progressive Differentiation, yaitu bahwa dalam belajar suatu keseluruhan secara umum harus terlebih dahulu muncul sebelum sampai kepada suatu bagian yang lebih spesifik.

4. Concolidation, yaitu suatu pelajaran harus dikuasai sebelum sampai ke pelajaran berikutnya, jika pelajaran tersebut menjadi dasar atau prasyarat untuk pelajaran berikutnya.

5. Integrative Reconciliation, yaitu ide atau pelajaran baru yang dipelajari itu harus dihubungkan dengan ide-ide atau pelajaran yang telah dipelajari terdahulu. Prinsip ini hampir sama dengan prinsip subsumption, hanya dalam prinsip integrative reconciliation menyangkut pelajaran yang lebih luas, umpamanya antara unit pelajaran yang satu dengan yang lainnya (Nanang Hanafiah, n.d.).

Menurut Soekamto dan Winata Putra di dalam tugas melaksanakan proses belajar mengajar, seorang guru perlu memperhatikan beberapa prinsip belajar berikut.

1) Apa pun yang dipelajari siswa, dialah yang harus belajar, bukan orang lain. Untuk itu siswalah yang harus bertindak aktif.

2) Setiap siswa belajar sesuai dengan tingkat kemampuannya.

3) Siswa akan dapat belajar dengan baik bila mendapat penguatan langsung pada setiap langkah yang dilakukan selama proses belajar.

4) Penguasaan yang sempurna dari setiap langkah yang dilakukan siswa akan membuat proses belajar lebih berarti.

5) Motivasi belajar siswa akan lebih meningkat apabila ia diberi tanggung jawab dan kepercayaan penuh atas belajarnya (Wahyuni, 2010).

\section{B. Simpulan}

Belajar adalah suatu aktifitas sadar yang dilakukan oleh individu melalui latihan maupun pengalaman yang menghasilkan perubahan tingkah laku yang mencakup aspek kognitif, afektif dan psikomotorik. Sedangkan Pembelajaran merupakan suatu sistem atau proses membelajarkan subjek didik yang direncanakan, dilaksanakan, dievaluasi secara sistematis agar subjek didik dapat mencapai tujuan-tujuan pembelajaran secara efektif dan efisien.

Pembelajaran dipandang dari dua sudut pertama sebagai suatu sistem (terdiri dari beberapa komponen yaitu tujuan pembelajaran, media pembelajaran, pengorganisasian kelas, evaluasi pembelajaran, dan tindak lanjut pembelajaran (remedial dan pengayaan)). Kedua pembelajaran sebagai suatu proses (terdiri dari kegiatan yang dilakukan guru mulai dari perencanaan, pelaksanaan kegiatan sampai evaluasi dan program tindak lanjut).

Tiga ciri-ciri belajar: (a) belajar merupakan usaha sadar dari seseorang, (b) belajar ditandai adanya perubahan tingkah laku yang mencakup seluruh aspek (kognitif, 
afektif, psikomotor), dan perubahan tersebut relative permanent, (c) perubahan tingkah laku tersebut diperoleh dari proses interksi dengan lingkungan dan latihan. Faktor-faktor yang mempengaruhi belajar dan pembelajaran yaitu faktor intern (fisiologis dan psikologis) dan faktor ekstern (keluarga, sekolah dan masyarakat). Lima prinsip belajar: Subsumption, Organizer Progressive Differentiation Concolidation Integrative Reconciliation.

\section{Daftar Rujukan}

Aunurrahman. (2009). Belajar dan Pembelajaran. Bandung: Alfabeta.

Indonesia, Tim Penyusun Kamus Besar Bahasa. (1996). Kamus Besar Bahasa Indonesia. Jakarta: Balai Pustaka.

Isjoni. (2009). Menuju Masyarakat Belajar: Pendidikan dalam Arus Perubahan (Cet II). Yogyakarta: Pustaka Belajar.

Komalasari, K. (2010). Pembelajaran Kontekstual. Bandung: Refika Aditama.

Komsiyah, I. (2012). Belajar dan Pembelajaran. Yogyakarta: Teras.

Mahmud. (2010). Psikologi Pendidikan. Bandung: CV Pustaka Setia.

Majid, S. A. A. dan A. A. (n.d.). At-tarbiyah wa Thuruqut Tadris (Juz I). Mesir: Darul Ma'arif.

Mufarrokah, A. (2009). Strategi Belajar Mengajar. Yogyakarta: Teras.

Nanang Hanafiah, C. S. (n.d.). Konsep Strategi Pembelajaran. Bandung: Refika Aditama.

Nara, E. S. dan H. (2010). Teori Belajar dan Pembelajaran. Bogor: Ghalia Indonesia.

RI, D. A. (2004). Al-Qur'an dan Terjemahanya: Juz 1 - Juz 30. Bandung: Jumanatul Ali Art.

Sahrani, P. S. dan S. (2011). Psikologi Belajar dalam Perspektif Islam. Bogor: Ghalia Indonesia.

Sardiman. (1994). Interaksi dan Motivasi Belajar Mengajar (Jakarta). PT. Grafindo Persada.

Shihab, M. Q. (2002). Tafsir al-Misbah; Pesan, Kesan dan Keserasian al-Qur'an, Vol.4 (Vol 15). Jakarta: Lentera Hati.

Slameto. (2006). Belajar dan Faktor-faktor yang Mempengaruhinya. Jakarta: Rineka Cipta.

Soekamto, T. (1997). Teori Belajar dan Model-model Pembelajaran. Yogjakarta: PAUPPAI.

Subroto, S. (1997). Proses Belajar Mengajar di Sekolah. Jakarta: Rineka Cipta.

Sudjana, N. (1989a). Cara Belajar Siswa Aktif. Bandung: Sinar Baru. 
Sudjana, N. (1989b). Media Pengajaran. Bandung: Sinar Baru.

Sukmadinata, N. S. (2004). Landasan Psikologi Proses Pendidikan. Bandung: PT Remaja Rosdakarya.

Sutikno, M. S. (1995). Belajar dan Pembelajaran: Upaya Kreatif dalam mewujudkan pembelajaran yang berhasil. Jakarta: Rineka Cipta.

Wahyuni, B. dan E. N. (2010). Teori Belajar dan Pembelajaran (Cet V). Jogjakarta: ArRuzz Media. 